\title{
Scheduling in Nordic Public Service Television
}

\section{General Description of an Ongoing Research Project}

\author{
ESPEN YTREBERG
}

The project aims to analyse and discuss the current scheduling practices of four Nordic public service television broadcasters. It follows the construction of schedules from the first initiation through the various stages of development to the implemented output. Attention is paid particularly to the discourses of scheduling that are in play, to the legitimation strategies and power relations of various professions and parts of the broadcaster organizations.

The project covers a total of 8 channels: DR and DR2 in Denmark, NRK1 and NRK2 in Norway, YLE TV1 and TV2 in Finland, and SVT1 and SVT2 in Sweden. The production of the schedule is investigated partly through interviews and partly on the basis of document material from the broadcasters. This material includes information about the shape and specifications of the schedule, from early drafts to the detailed computerised systems that integrate scheduling, programming and resources allocation. Also, the actual audiovisual output is analysed qualitatively, focussing on the schedule's main outlines and on the way that continuity segments produce images of channel identity. The project emphasises a comparative approach to the different broadcasters' scheduling. It pays particular attention to the way that all four Nordic broadcasters currently operate coordinated two-channel systems. The project is financed by the Nordic Council of Social-Scientific Research (NOS-S). It started up in August 1999, and lasts until the end of 2000.

Department of Media and Communication, University of Oslo, P.O. Box 1093, Blindern, NO-0317 Oslo, espen.ytreberg@media.uio.no

\section{Nordic Public Service Broadcasting in Transition}

In the Eighties and Nineties Nordic public service broadcasting has undergone fundamental changes. It has followed the international trend of deregulation and increasing competition. These developments have been the subject of investigation by Nordic researchers, and many of the central processes of change are well documented (Syvertsen 1997, Søndergaard 1994, Hellman 1998). However, in many ways the wider impact of these changes remains to be assessed. It is often characterised as amounting to commercialisation, in a process where the ideals of public service are displaced by a market-oriented race for high ratings and attractive segments. But the changes can also be seen as signs of an increasing awareness of viewer's needs and interests.

This could be interpreted to mean that broadcasters orient themselves away from an earlier "paternalism" toward a more democratic attitude. Seen in this more positive light the recent modernization of public service broadcasting may be on the path to realizing the ideal of serving the public.

In the last instance these are issues for the public to debate. However researchers may aid the debate by continuing to probe into the processes and discourses that shape the broadcasters' output. Traditionally researchers' investigations have been concentrated on the media-political level, supported by output statistics. The relations between broadcasters, regulators and politicians have been at the center of interest. However in recent Nordic public service research of the Nineties a greater emphasis has been put on processes of scheduling and programming. This has happened largely as a 
result of Nordic public service broadcasters' encounter with ever-stiffening competition. The new environment has profoundly affected programming and scheduling alike, as well as the relations between them. Hence there is a need for research that looks more closely at the processes of power, initiative and decision going on inside the broadcasters. And in this context scheduling stands out as in many ways the new center of power in Nordic public television broadcasters.

\section{Approaches to Scheduling}

In the American research literature, "scheduling" traditionally names the process of producing a framework of time-structured "slots" to be filled with programmes. The process of scheduling is closely connected to the processes of "programming", of selecting programmes, producing them and finding an outlet for them. (Blum \& Lindheim 1987, Eastman et al 1989) The schedule provides a broadcaster with a means of presenting its programmes in accordance with the broadcaster's overall goals of programme policy. Research on scheduling has concentrated on the main outlines of schedules, such as the demarcations of prime time and the degree of slot uniformity. But in principle the process of scheduling may also characterise the more detailed filling-in of the channel's continuity segments in-between programs. The analysis of scheduling involves seeing scheduling practices in their organizational, economic, cultural and ideological context. In Nordic and British research schedule analysis has been used to highlight the connection between practices of scheduling, structures of the television output itself and practices of audience use (i.e. Paterson 1990, Søndergaard 1994, 1997).

In the Nordic tradition of public service television monopolies, scheduling strategies were nowhere near as developed and prominent as was the case with commercial broadcasters. Scheduling came into prominence as monopoly was replaced by competition. During the Eighties and early Nineties scheduling was transformed from a relatively marginal and modestly coordinating role to becoming a high priority with the broadcasters themselves (Björkegren 1996, Hellman 1998, Syvertsen 1997, Søndergaard 1994). At the same time the organzations of the broadcasters changed from being modelled on state bureaucracies toward being modelled more after private sector organizations geared to the needs of competition. The organizations were restructured to accommodate new professionals who were engaged in scheduling, and who became closely involved in overall policies and planning.

As a result of these developments, today's scheduling in the Nordic public service broadcasters is established as a distinct site of power over output and resource allocation. In the course of schedule construction, and following from its needs, a host of crucial decisions are made about programme policy, allocation of production and service resources, about budgeting and about the administration of personnel. The broadcasters' executives and schedule planners now construct a schedule in great detail, linking it to contracts and budgets, and to quantified goals of audience rating. Through an intensified appeal to the viewer and through competitive programming and scheduling strategies the public service broadcasters attempt to enter into a new relation with their viewers. In this new set of priorities scheduling is not just important for the way output is structured. Increasingly it influences what programmes are made and how. During the Nineties a number of broadcasters (among them the Nordic ones) have been in the process of making scheduling still more of an independent and powerful factor, by separating the functions of production and coordination/distribution organizationally. (Mulgan \& Paterson 1993) The projected digitalization of television is expected to influence distribution greatly in the years ahead. Thus the strategies of scheduling may change, but it seems to be a permanent fact that scheduling operates as a distinct and powerful factor in public service broadcasting.

Scheduling is rarely given much attention from politicians, the state or the public - at least compared to programmes and programming. However the rise of scheduling in Nordic public service broadcasting raises a number of important issues. It would seem that it has taken the broadcasters of the Eighties and Nineties toward practices that are characteristic of commercial broadcasters, both in terms of scheduling and programming. However it remains to be investigated just what kind of adaptation this has been, how far it has gone, and what other factors may come into play. The project aims to investigate these issues through an analysis of current scheduling practices. It also looks at the phases of programming where it is shaped by the needs of scheduling - and vice versa. Another key determinant of the schedule is the way that it is strategically planned to compete, complement or contrast with other channels. To account for this the project has several comparative foci. Firstly it compares the former monopoly broadcasters of the four Nordic countries. More specifically it compares 
how the four broadcasters all employ a two-channel system. And it looks at how the broadcasters see their two channels in relation to the total broadcasting situation in their national contexts. In discussing its findings the project draws on the considerable international research literature on public service television. (i.e. Achille \& Miège 1994, Blumler \& Hoffman-Riem 1992, Raboy 1996, Tracey 1998)

\section{Definitions and Main Research Questions}

For the purposes of this project, "scheduling" includes:

- the concrete process of generating and developing the schedules themselves, from the first, informal planning stages to the later use of elaborate computer-administered scheduling systems.

- the discourses of professional knowledge and the strategies of legitimation that the scheduling process involves. This includes discourses on policy, on viewers, and on evaluation.

- the way that the scheduling process interacts with and influences processes of programming, of resource allocation and on budgeting.

The project analyses and discusses these aspects of scheduling using the following key research questions:

1. What main principles dictate the composition of the schedules? Particularly interesting is the question of how these main principles relate to established scheduling principles in commercial broadcasting. At the same time it is important to avoid foregone conclusions, and to look for other criteria that may indicate a qualitatively different approach to viewers and to scheduling than that of commercial operators.

2. How is power distributed and exercised between those in charge of coordinating channel output (typically heads and directors of planning) and those in charge of programming (typically heads of department and heads of programming)? For all Nordic broadcasters it seems clear that scheduling concerns have grown in importance over the last two decades. Still schedulers have not necessarily become independent of the process of programming and its traditionally strong influence on the scheduling process in public service broadcasters.
3. How are the processes and the main principles of scheduling reflected in the schedules' main outlines? As for the general characteristics of the schedules it is relevant to look at the types of "slotting" and "stripping" that predominate. Existing research also indicates that the placing and duration of prime time for purposes of competition is a central issue. (Hellman \& Sauri 1996, Syvertsen 1997) Also the division of labour and the principles of complementarity between the schedules in two-channel broadcasters is a key topic for investigation.

4. How are the processes and main principles of scheduling reflected in the schedules at segment level? Here analysis will focus on the continuity elements of the schedule, that is, on the "pauses" between programmes. Of particular interest are the overarching thematics and the modes of address characteristic of the channel. Existing research indicates that competition has changed the schedule considerably in both areas. There are tendencies toward an appeal to the viewer that is both more intensified and more informal, and there is a constant effort to build various thematics of community, such as "the family" and "the nation" (Hjarvard 1994, Søndergaard 1997, Ytreberg \& Orgeret 1997). Here, too, a comparison between the two channels will be important in building a total picture of the broadcaster's output.

\section{Theoretical Perspectives}

An analysis of scheduling in public service broadcasting as outlined above presents certain challenges of theory that the project will discuss:

\section{Public Service Broadcasting as Cultural Industry}

As mentioned earlier, existing research approaches to public service have taken media-political and normative-theoretical approaches that need to be complemented. (i.e. Garnham 1986, Mortensen 1978, Murdock 1990, Syvertsen 1992) The broadcasters' adoption of modes of organisation that are characteristic of commercial operators make it clear that researchers are dealing not just with instruments of media politics, but with forms of cultural industry (Lowe \& Malm 1997, Ytreberg 1998). Following on from this, the principles of public service may be seen not just as a product of discourses in 
the interface between politicians, regulators, the public and the broadcasters. It is also a factor in discourses that operate where schedules and programmes are actually planned and implemented. And there is no a priori reason to see this latter level of discourses on public service as any less important than the first.

Viewing public service as cultural industry means seeing its discourses and strategies of legitimation as products of television's modes of organization. A body of literature within the sociology of organizations and their cultures provides a possible framework for understanding this (i.e. Bagguley 1991, Hesmondhalgh, Lash \& Urry 1994) Under the labels of "post-fordism" and "enterprise culture" it discusses structural changes in modern organizations brought on by the new technologies and increasing commercial pressures of the Eighties and Nineties. Developments include organizational concentration round the "core" activities of coordination and distribution, accompanied by a downsizing and outsourcing of production. Also central to this transformation of organizations are new organizational ideologies such as the notion of "enterprise", of "flexibility" and "service". The services and media sectors have been central in discussions of post-fordism and enterprise. In the public service context they come to the fore particularly in connection with the new management ideal of the Nineties, "producer's choice". (Mulgan \& Paterson 1993) The idea of producer's choice very much ties in with developments toward a stronger and more independent role for scheduling. Thus theories of post-fordism and enterprise culture seem promising as frameworks for discussing the logic and the legitimation strategies of current scheduling practices.

\section{The Schedule as Text}

In media research there has been a tendency for social-scientific content analysis and humanistic textual analysis to converge. As a result some researchers employ a qualitative approach that combines attention to textual nuances and macro-structures with a social-scientific interest in the texts' (institutional) context (Several discussions of this convergence come from the Nordic research community, i.e. Ekecrantz 1998, Jensen 1991). This process has been driven in part by the need to handle texts that come continuously and in copious quantity, with no established canon to single out certain texts for close investigation.
Television schedules are in many ways the archexample of such an accumulated text "mass". Accordingly the research on television schedules may serve as a point of departure for general discussions of the concept of the text in media research. It highlights the need for research approaches that find workable alternatives to the traditional, elite-cultural concept of the text-as-single-program. There is a clear need for further development of textual concepts that characterise the overall structures of schedules, without resorting to conceptualisations that are too general to be analytically effective. In international research literature there exists a basic discussion of this, chiefly in Williams (1975) and Ellis (1988). However there have been few initiatives to develop its insights further (exceptions are Morse 1985, Newcomb 1988). The project's discussion will build on existing Nordic approaches to the analysis of modes of address and thematics in television continuity segments.

\section{Methodologies and Empirical Data Interdisciplinarity}

As outlined above, the project takes an interdisciplinary approach to the analysis of media institutions, combining sociological perspectives on organization and culture with qualitative analyses of schedules. These analyses of schedules constitute an example of interdisciplinarity in itself. It combines an analysis of textual features with an analysis of the pragmatic aspects of scheduling, the intentions and strategies that actors in the scheduling process employ to shape it. In this respect it builds on a combination of methodologies that already been tried and tested in Nordic analyses of public service television institutions (Hellman 1999, Syvertsen 1997, Søndergaard 1994, Ytreberg 1998). It seeks to develop the approach partly by investigating the scheduling process considerably closer than has been done up till now. And it seeks to integrate further the analysis of organizational processes, discourses, documents, and texts.

The process of planning and developing the schedules will be investigated partly through qualitative interviews and partly through analysis of documents from the broadcasters. 10 to $15 \mathrm{semi}$ structured interviews will be conducted per broadcaster. Interviewees will be sampled from broadcaster and channel management, heads of planning and programming, from various levels of schedule implementation, as well as from the research and in- 
formation departments. Of course all document material related directly to the scheduling process is vital: the schedules themselves in different versions and states of elaboration, budgets, contracts, memoranda and protocols of meetings. Important too are internal plans and memoranda on scheduling and programming both on broadcasting and channel levels. The gathering of interview and document material focuses on scheduling processes that went on in the broadcasters throughout 1998, and that concerned schedules for the year 1999 .

\section{Analysing Schedules}

Analyses of the textual features will build both on what is commonly called "document material " and "texts" in the shape of video material. In current media research there remains a considerable methodological divide between the two, although media researchers analyse both documents and texts qualitatively, with a basis in hermeneutics and social semiotics. The schedules of modern television exemplify how closely related documents and texts can be; there is virtually a seamless process from initial schedule outlines to the extremely detailed schedules that are used as a "blueprint" for the actual output. There is of course a significant transfer of media when these computer-based schedules are implemented as broadcast audio-visual texts. However both may be used to analyse the schedule's main outlines and the segments in-depth. All stages, from the early schedule sketches to the implemented schedule output, will be treated as containing relevant information both on overall outlines and textual detail.

The project, then, will draw on existing analyses of general schedule outlines, and hence concentrate on strategies such as stripping, slotting and prime time placement (Blum \& Lindheim 1987, Eastman et al 1989, Hargrave 1995, Søndergaard 1994, Syvertsen 1997). Early versions of the schedule is likely to provide more information on this than on modes of address and thematics of community. These aspects are likely to come more to the fore as the schedule is developed, in its later and elaborate stages. In the analysis of implemented schedules thematics and modes of address will come still more to the fore, as the audio-visual material is likely to provide the greatest wealth of information on schedule design.

The videotaped material will also be used to complement the analyses of general schedule outlines. However the selection of videotaped material will be made primarily with the in-depth analysis of continuity in mind. This means it will be to small to be representative of the broadcasters' universes of output. The videotaped material will consist of five days' broadcasting (the weekend and 3 weekdays) from the project's 8 channels in November 1999. It will be restricted to the time period leading in to prime time, prime time itself, and the late evening period. General descriptions and analyses of the broadcasters' schedules for the year 1999 will be based on the document material, and on its degree of generalizability. Also the project will draw on existing quantitative research on the Nordic broadcasters' output. (Hellman \& Sauri 1996, Hultén 1996, Nielsen \& Svendsen 1996)

\section{The Comparative Aspect}

There are several reasons why a comparative approach to the analysis of public service broadcasting makes sense in the Nordic context. The Nordic countries provide a set of broadcasters that have similar backgrounds, sharing a history as dominant monopoly broadcasters with mandates to enlighten, reform and unite the national public. They also share a history of Anglo-American influence, particularly from the BBC. Partly as a consequence of these common denominators, Nordic research on public service broadcasting has developed a degree of common direction and a set of shared competences (as documented in the anthologies of Bono \& Bondebjerg 1994, Hultén et al 1996). At the same time the broadcasters are sufficiently different to provide analytically productive contrasts. They include both licence-based broadcasters and various combinations of licence and advertising funding. There is a wide spectrum of traditions and practices in coordinating channels, reflecting different histories of channel institutionalization. On the one hand Sweden and Finland have long histories of two channels that have been partly complementary and partly competing. On the other the cases of Denmark and Norway show on major channel that has recently spawned a small channel that supplements and contrasts with alternative and minority programming.

The project is closely coordinated between its four cases and researchers. The same main research questions, theoretical framework and methodological approach is applied by all researchers. Also the gathering of empirical material and the initial treatment of the empirical material is done in concert, although here the individual researchers have some leeway in adapting to the needs of their national contexts. The analyses and the reporting of findings 
will done in various degrees of collaboration, with a general emphasis on inter-country comparison. Plans for publication include reports on each broadcaster, an English-language book-length publication, and an English-language article.

\section{References}

Achille, Y. \& Miège, B. (1994) The Limits to the Adaptation Strategies of European Public Service Television, $\mathrm{Me}$ dia, Culture and Society 16.

Bagguley, P. (1991) Post-Fordism and Enterprise Culture. Flexibility, Autonomy and Changes in Economic Organization. In Keat, R. \& Abercrombie, N. (eds.) Enterprise Culture. London: Routledge.

Björkegren, D. (1996) TV som företag. In Hultén, O. et al (eds.) Nordisk forskning om public service. Göteborg: Nordicom.

Blum, R. \& Lindheim, R.D. (1987) Primetime: Network television Programming. Boston: Focal Press.

Blumler, J. \& Hoffman-Riem, W. (1992) New Roles for Public Television in Western Europe: Challenges and Prospects, Journal of Communication 42 (1).

Bono, F. \& Bondebjerg, I. (1994) Television in Scandinavia - History, Politics and Aesthetics. Luton: Luton University Press (John Libbey Media).

Eastman, Susan T. et al (eds.) (1989) Broadcast/Cable Programming. Belmont: Wadsworth.

Edin, A. (1996) Public service och kontakterna till allmänheten och publiken. In Hultén, O. et al (eds.) Nordisk forskning om public service. Göteborg: Nordicom.

Edin, A. (1998) Well-Ordered Competition. The TwoChannel System in Swedish Television, Nordicom Review 1.

Ekecrantz, Jan (1998) Media, Communication and Social Critique, Nordicom Review 19 (1).

Ellis, J. (1988) Visible Fictions: Cinema-Television-Video. London: Routledge.

Garnham, N. (1986) The Media and the Public Sphere. In Golding, P. et al (eds.) Communicating Politics. Mass Communications and the Political Process. Leicester: Leicester University Press.

Hargrave, A.M. (1995) The Scheduling Game. London: John Libbey/Broadcasting Standards Council.

Hellman, H. \& Sauri, T. (1996) Konvergens och mangfald i de finska TV-kanalerna. TV-reformens påverkan på prime time-programutbudet 1988-1995. In Hultén, O. et al (eds.) Nordisk forskning om public service. Göteborg: Nordicom.

Hellman, H. (1998) From Companions to Competitors. The Impact of Competition and Particularly the 1993 Television Reform on Programming Policies and Programme Output in Finland. University of Tampere: Dept. of Journalism and Mass Communication.
The project's researchers welcome contact and exchange with Nordic and international researchers who work on scheduling, and/or who are engaged in similar research projects.
Hesmondhalgh, D. (1996) Flexibility, Post-Fordism and the Culture Industries, Media, Culture \& Society 18.

Hjarvard, S. (1994) Intimitet, autenticitet og kvindelighed. Om offentlighedens forandringer og public service TV's iscenesættelse af autoritetstabet. In Dahlgren, P. (ed.) Den mångtydiga rutan. University of Stockholm: JMK, report series 1994:1.

Hujanen, T. (1993) Ajankohtainen kakkonen kohtaa historiansa [A generic history of the current affairs programs of Television 2]. Helsinki: The Finnish Broadcasting Company, research report 9.

Hujanen, T. (1998) The New Competitive Environment of Radio Broadcasting in the Nordic Countries: A Short History of Deregulation and Analysis of Recent Trends, Journal of Radio Studies 5 (1).

Hultén, Olof (1996) Det svenska TV-utbudet 1987-1994. Sändningstid och programkategorier. In Hultén, O. et al (eds.) Nordisk forskning om public service. Göteborg: Nordicom.

Hultén, O. et al (eds.) (1996) Nordisk forskning om public service. Göteborg: Nordicom.

Jensen, K.B. (1991) Humanistic Scholarship as Qualitative Science: Contributions to Mass Communication Research. In Jensen, K.B. \& Jankowski, N.W. (eds.) A Handbook of Qualitative Methodologies for Mass Communication Research. London: Routledge.

Lash, S. \& Urry, J. (1994) Economies of Signs and Space. London: Sage.

Lowe, G.F. \& Malm, A. (1997) Public Service Broadcasting as Cultural Industry, European Journal of Communication 12 (2).

Mortensen, F. (1978) Ytringsfrihed og offentlighed. Århus. Morse, M. (1985) Talk, Talk, Talk: The Space of Discourse in Television News, Sportcasts, Talk Shows and Advertising, Screen 26 (2).

Mulgan, G. \& Paterson, R. (eds.) (1993) Reinventing the Organisation. The BBC Charter Review Series, London : BFI.

Murdock, G. (1990) Television and Citizenship: In Defense of Public Broadcasting. In Tomlinson, A. (ed.) Consumption, Identity and Style. London: Routledge.

Newcomb, H. (1988) One Night of Prime Time: An Analysis of Television's Multiple Voices. In Carey, J.W. (ed.) Media, Myths and Narratives. Television and the Press. Beverley Hills: Sage.

Nielsen, A.P. \& Nordahl Svendsen, E. (1996) Public service som seernes valgmulighed. In Hultén, O. et al 
(eds.) Nordisk forskning om public service. Göteborg: Nordicom.

Paterson, R. (1990) Planning the Family: The Art of Scheduling. In Goodwin, A. \& Whannel, G. (eds.) Understanding Television. London: Routledge.

Syvertsen, T. (1997) Den store TV-krigen. Norsk allmennfjernsyn 1988-96. Bergen: Fagbokforlaget.

Søndergaard, H. (1994) DR i tv-konkurrencens tidsalder. Frederiksberg: Samfundslitteratur.

Søndergaard, H. (1997) Public service i receptionsæstetisk perspektiv. Paper til den 13. nordiske konferansen for massekommunikasjonsforskning, Jyväskylä.
Tracey, M. (1998) The Decline and Fall of Public Service Broadcasting. Oxford: Oxford University Press.

Williams, R. (1975) Television - Technology and Cultural Form. New York: Schocken Books.

Ytreberg, E. \& Orgeret, K.S. (1997) Allmennfjernsynets nye fasade: En kvalitativ programflateanalyse av NRK, Norsk medietidsskrift 4 (1).

Ytreberg, E. (1998) Allmennkringkastingens autoritet: Endringer i NRK Fjernsynets tekstproduksjon, 198894. University of Oslo: Dept. of Media and Communication report series 35 .

\section{Addresses and participants}

Head of research project

Ph.D. Espen Ytreberg

Main project address:

Dept. of Media and Communication

University of Oslo

P.O. Box 1093 Blindern

NO-0317 Oslo

Norway

E-mail: espen.ytreberg@media.uio.no

Other researchers

Ph.D. Anna Edin

Dept. of Journalism, Media and Communication

University of Stockholm

P.O. Box 27861

SE-115 93 Stockholm

Sweden

E-mail: anna.edin@jmk.su.se
Professor Taisto Hujanen

Dept. of Journalism and Mass Communication

University of Tampere

P.O. Box 607

FIN-33101 Tampere

Finland

E-mail: titahu@uta.fi

Senior lecturer, Ph.D. Henrik Søndergaard Dept. of Film and Media Studies

University of Copenhagen

Njalsgade 80

DK-2300 Copenhagen S

Denmark

E-mail: henriks@ coco.ihi.ku.dk 